Alescander 8. Galley. fe, with the complement e of gulf 28,1920. Athene ex Payne.

[From 'The Auk,' Vol. XXIV, No. 4, October, 1907.]

OBSERVATIONS ON SOME BIRDS PROCURED NEAR CHARLESTON, SOUTH CAROLINA.

BY ARTHUR T. WAYNE. 


\title{
OBSERVATIONS ON SOME BIRDS PROCURED NEAR CHARLESTON, SOUTH CAROLINA.
}

\author{
BY ARTHUR T. WAYNE.
}

Colymbus auritus. Horned Grebe.-This Grebe is exceedingly abundant from November until the middle of March, but it is rare to obtain one in full adult nuptial plumage while the birds sojourn here, as they commence to migrate long before the breeding plumage is acquired. The change from winter to summer plumage begins about the 10th of March. A specimen taken April 7, 1888, was assuming the characteristic nuptial plumage, while a bird shot on March 21, 1906, has the throat mottled with black and the fore neck pale chestnut.

Dr. Eugene Edmund Murphy took a specimen in almost perfect nuptial plumage at Cape Romain on May 15, 1904, and the writer procured a male near Mount Pleasant, on June '5, 1907, which very closely resembles the bird taken by Dr. Murphy. Both of these birds were in good condition, and not wounded, hence it is remarkable that they should have remained on this coast so late in the season of reproduction.

Nyctanassa violacea. Yellow-CRowned NigHT Heron.On March 23, 1907, the writer shot a female of this handsome 
species, and upon examination found the abdomen bare and the skin wrinkled showing that incubation was going on even at this early date. Upon dissecting the specimen it was found that two eggs had been laid, while the third, which would have been the last, was almost ready for extrusion. As far as my information on the breeding of this species goes this is the earliest record for the South Atlantic States, with the possible exception of the southern part of Florida. It must be borne in mind, however, that the winter of 1907 was exceptionally mild, and July and August temperatures prevailed during the latter half of March. The day on which this heron was shot the thermometer registered 94.2 degrees.

Helminthophila bachmanii. BACHMAN's WARBLER.-During the month of March, 1907, I kept a sharp lookout in suitable localities near my home for the arrival of this rare warbler, but although I was in the woods almost daily no birds were observed until the breeding ground was visited, when six pairs were located in various parts of the swamp where the first nests and eggs were taken in April, 1906 (see Auk, XXIV, Jan., 1907, pp. 43-48). Some of the birds must have certainly arrived not later than February 28 or March 2, as the first nest, found on March 27, contained one egg. This nest was left until the 30th, when it contained four fresh eggs and the female was incubating.

On April 3 I found a nest which contained five eggs far advanced in incubation. This nest and eggs was found within fifty feet of the spot where the first nest was taken on April 17, 1906, and doubtless belonged to the same pair. This nest was evidently commenced on March 9, and as it requires fourteen days for the completion, and five days in which to deposit five eggs, it will be seen that on March 27 or 28 incubation must have just begun, as the eggs were undoubtedly incubated for at least eight or nine days. These nesting dates are important, and prove that although this species does not winter it is one of the earliest migrants in the spring and breeds even earlier than the resident Yellow-throated (Dendroica dominica) and Pine Warblers (Dendroica vigorsii). It also proves that the birds which breed in South Carolina reach their summer home much earlier than those which migrate along the Gulf coast States and breed in the Mississippi Valley, for the Bachman's Warblers that breed in the low coast region of this State undoubtedly migrate along the Atlantic coast. 


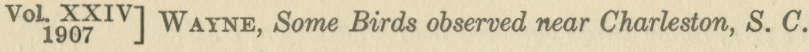

At Branford on the Suwannee River, Florida, the writer first met and secured this warbler on March 14, 1892, while migrating birds were noted until April 2. The next year I was collecting at Old Town, sixty miles down the Suwannee (from Branford), and took the first Bachman's Warbler on March 10, the birds being noted until the $22 \mathrm{~d}$ of the month, when all had apparently gone north.

In 1894 I obtained the first specimen on March 13 at the headwaters of the Wacissa River, Jefferson County, Florida. Although I recorded this bird as a migrant (Auk, Vol. XII, October, 1895, p. 367) I now believe that it breeds locally and sparingly near the village of Waukeenah.

On March 30, 1907, I shot a fine male of this warbler near Mount Pleasant from near the top of a huge water-oak tree some eighty feet above the ground. It was singing exactly like a Prothonotary Warbler (Protonotaria citrea), and when I went to locate the singer I was surprised to see that it was not that warbler, but one with a black throat and breast patch. The bird sang constantly, and as the song was identical with that of the Prothonotary I concluded that it must have been either the Golden-winged (Helminthophila chrysoptera) or Lawrence's Warbler (H. lawrencei) - forms I have not seen in life - and determined to secure it, which I did, after having heard it sing for more than twenty minutes. Upon securing the specimen I was amazed to find that it was in reality a Bachman's Warbler. This song must be very rare or else produced by a bachelor male.

Helminthophila celata orestera. Rocky Mountain OrangeCROWNED WARBLER.- On December 6, 1893, I shot a very large and richly colored specimen $\left(\sigma^{\top} \mathrm{ad}\right.$.) of what I supposed was the Lutescent Warbler (Helminthophila celata lutescens). I sent this bird to my friend Mr. William Brewster for determination, and under date of January 25, 1894, he wrote concerning the specimen as follows: "The Orange-crowned Warbler is not lutescens. It is not nearly yellow enough but matches closely the birds which occur in Texas and the Mississippi Valley generally."

In 'The Auk,' XXII, July, 1905, pp. 243-245, Mr. Harry C. Oberholser described under the name Vermivora celata orestera a new form of the Orange-crowned Warbler from the mountains 
of New Mexico. Having the specimen in mind that I sent to Mr. Brewster in January, 1894, I wrote him in August, 1905, for the loan of it. He very kindly forwarded the specimen, together with a large series of specimens of the form celata from Colorado Springs, Colorado, that he personally collected. Upon comparing the South Carolina bird with Mr. Brewster's series from Colorado I found that the former was even more richly colored than any of the latter and was an ultra typical example of Mr. Oberholser's new race, orestera. This discovery led me to examine my South Carolina specimens of Orange-crowned Warblers, that I had packed away for many years, and the result was I found no less than three birds clearly referable to orestera, as follows: January 2, 1890, male; February 11, 1891, male; December 3, 1896, male, all of which were taken near Mount Pleasant.

The bird taken December 3, 1896, is an ultra typical example of orestera while the others are nearer that form than celata.

This new race is supposed to be a Rocky Mountain breeder, and Prof. W. W. Cooke ${ }^{1}$ is of the opinion that no bird (which breeds in these mountains) migrates to the Atlantic Coast unless it breeds in the Mackenzie River region.

If this form is entitled to recognition another far western bird is added to the fauna of South Carolina.

Dendroica tigrina. CAPE MAY WARBLER.- This beautiful species is a regular although rare autumnal migrant along the coast, but I have not as yet detected it in the spring. Up to 1905 my latest autumnal record was October 18, and the earliest September 8. On October 31,1906 , I shot a young male in my yard, which was feedingtamong some lavender bushes, and on November 3 I secured a young female at the same spot where the male was obtained.

All the early migrating Cape Mays have been adult birds, whereas the latest migrants are invariably the young of the year, which is indeed very strange. At Chester, Mr. Leverett M. Loomis noted this warbler from October 4 to 26 (Auk, VIII, April, 1891, p. 170). It will be seen that the birds arrive near Charleston nearly a month earlier than at Chester.

Dendroica striata. BLACK-POLL WARBLER.-The Black-poll

${ }^{1}$ W. W. Cooke, in epist. 
Warbler is abundant during both migrations, but more abundant in the autumn than in spring. On November 14, 1906, I procured a female in my yard. The day upon which the bird was shot the thermometer registered $28^{\circ}$. My latest previous record is October 29,1894 , and as far as I am aware the bird taken November 14, 1906, is the latest record for the United States with the exception of one from southern Florida taken or observed on November 16, 1887. (See Distribution and Migration of North American Warblers, Bull. Biol. Survey, No. 18, 1904, by Wells W. Cooke.)

Sitta canadensis. Red-BREAsted Nuthatch.- In 'The Auk,' XIII, 1896, p. 85, the writer recorded two birds of this species from Long Island, taken November 14, 1895. Since these birds were observed I have found the species to be an irregular autumn and early winter visitor, as the following records will show: Long Island, November 27, 1901. Shot six and saw upwards of a hundred in pine and cedar woods; also shot two on December 26 at the same place. Dewees Island, December 18, 1903. Took an adult male. Oakland plantation, Christ Church Parish, October 29, 1906. Shot an adult male, the specimen being the only one I have as yet observed on the mainland. My friend Mr. Herbert Ravenel Sass observed two birds in his garden in Charleston on October 29, 1906. Long Island, November 3, 1906. Saw upwards of twenty-five and obtained two. Dewees Island, November 17, 1906. Shot two males and observed perhaps thirty individuals.

This species shows moult when it arrives, and as long as it remains, which is certainly remarkable. The birds feed upon the seeds of the pine and cedar and seem to be particularly fond of the seeds of the latter tree. While the birds have been common in November, 1901, and November, 1906, they apparently do not remain through the winter months, but disappear almost as suddenly as they arrive. Mr. James P. Garick, Jr., informs me that the birds were very abundant at his home in Weston (a few miles south of Columbia) in the autumn of 1906, and I have a very high plumaged male taken by him on October 10, 1906.

Polioptila cærulea. Blue-Gray Gnatcatcher.-Although this species is said to winter from "Florida southward" by Mr. Chapman (Birds of Eastern North America, 1895, p. 394) and also by Mr. Ridgway (Birds of North and Middle America, Part III, 
1904, p. 718) who says: "wintering in Florida and other Gulf States," these statements are misleading and inaccurate, for the Blue-gray Gnatcatcher winters regularly on the coast of South Carolina. I have long known this fact, for on December 15, 1885, I saw about a dozen birds near Charleston and shot four specimens; while in January, 1886, others were noted during the memorable blizzard, and which was the coldest weather up to February, 1899. I herewith mention a few dates on which others were taken: January 10, 1889, one; January 2, 1893, one; December 26, 1898, saw two and obtained one; February 4, 1903, one. All the specimens taken are apparently immature birds and the question is where do the adults winter? As they are presumably more hardy than the young the assumption would be that they, or at least some of them, winter at points along the coast to the northward of Charleston. This is, however, not the case as there are no records of the birds wintering in North Carolina. Why the young of this species should winter and not the adult is certainly very strange. 